be changed from $960^{\prime \prime} \cdot 78$ to $961^{\prime \prime} \cdot 50$, this alteration being based on the discussion of 35,842 meridian observations made at the principal observatories of the world.

A new departure in the administration of the Observatory was the appointment, in June. I 899, of a Board of Visitors by the Secretary of the Navy, whose duty will be to examine and report upon the condition and requirements of the institution.

\section{ON THE BLUE COLOUR IN WOAD.}

"THE old East Anglian proverb, "As blue as wad," occurs to one visiting the Woad Mill described by Mr. Darwin in NA'TURE, in 1896 (vol. lv. p. 36), as evidence that woad once yielded a blue dye. As a natural sequence one wonders what sort of blue it was and how it was obtained. A somewhat extended series of inquiries amongst those engaged in the woad industry, amongst those who have written on woad, and amongst botanical, archæological and chemical friends, failed for a long time to elicit the desired information. Curious as it may appear, an appeal to botanical and chemical works, to dictionaries and encyclopxedias was equally unsuccessful. The last-named were pretty uniform in their statements about woad, in that it "was formerly used for dyeing blue, but is now superseded by indigo." Many of the books give an account of the woad-vat in which the manufactured woad is used with bran and lime as a ferment to change the insoluble indigo-blue into the soluble indigo-white; but they give no clue as to how woad may be used as a blue dye alone. It has been said that the blueness of woad was more or less a myth, and even if it ever possessed this quality it has long since been lost by continued cultivation.

As some of the facts elucidated in the attempt to find the blue colour may be of interest to others, they are herewith detailed :-

At the present time woad is grown and is manufactured in four places in the Fen country, viz. at Algarkirk, Wyberton, Skirkbeck, and Parson Drove; its use being as above stated, as a ferment in the indigo-vat to dissolve the indigo-blue. This process of dyeing by woad is difficult, cumbersome and expen. sive, but it yields the most permanent results. A genuine woaddyed cloth resists sunshine, rain, and sea-air better than any other, but it is so expensive that only the very best articles are dyed in this way. The fastness of woad-dyed cloth is so proverbial that Prof. Hummel, of the Yorkshire College, Leeds, tells me the adjective "woaded" is now applied in the trade to any fast or permanent indigo dye : a woaded black meaning a black that has an indigo ground colour. The wool is dyed before it is woven, and the cloth may be distinguished by having pale blue or yellow threads in the selvedge.

But to return to the plant, many methods have been suggested by which the indigo in it may be extracted. In the earlier years of the present century, when we were at war with France, so great was the difficulty experienced by that nation in obtaining indigo that the Government offered a substantial prize for an efficient substitute. Attention was consequently re-directed to woad, and more than one method was suggested for the separation of indigo from it. However effective these may have proved in France and Italy, with me they failed, and failed so uniformly as to render the very numerous experiments extending over a period of five months unworthy of further notice. Suffice it to say that the experimental material was obtained from Parson Drove, Boston, Cambridge Botanic Gardens, and wild plants from Gloucestershire. Eventually the presence of indigo was demonstrated in these plants by the simple method of Dr. Hans Molisch, ${ }^{1}$ who kindly further advised me, in a letter, to examine particularly the younger and expanding leaves. The method consists in keeping the fresh leaves for twenty-four hou's in an atmosphere of ammonia, and then for a similar period in absolute alcohol. The ammonia precipitates the indigo in the leaves, while the alcohol dissolves out the chlorophyll : so that by cutting sections one can see the exact tissues in which the indigo occurs. These are those containing chlorophyll. The fibrovascular tissue, the hairs, the epidermis, excepting the guard cells of the stomata, are free from it.

The quantity of indigo varies very much in different leaves some turn a beautiful blue, while others come out of the absolute

I "Ueber das Vorkommen von Indican im Chlorophyllkoin der Indicanplanzen." " Berichten der Deutsch Botan. Gesell.," 1899. Bd. xvii Hf. 6 , p. $228, t$, xviii.)

NO. 1579 , vOL. $61 j$ alcohol showing only a faint trace towards the base of the leaves. As a rule, the younger the leaf the more indigo it contains; some young leaves, however, hardly contain any. Old leaves have practically none in them, and become yellowish-green or greenish-white brittle objects after the above treatmert.

The process of separating the indigo is more delicate- perhaps it would be more correct to say it is a process simple enongh in itself, but one in which certain precautions must be observed. Prof. Beijerinck, whose paper "On the formation of indigo from woad" is summarised in NATURE, November 16 , I899 (p. 7 I), gives the following method: The woad leaves are put into a stoppered bottle, which is then filled with hot water, in such a way that all the air is expelled and the stopper put in so that no air bubble is allowed to remain between the top of the water and the lower part of the stopper. The water assumes a pale yellowish tint-the colour of sherry-with a green fuorescence. On the addition of a caustic alkali it darkens and becomes greenish. If a dilute acid be now added the indigo falls as a blue precipitate. The first time this method was tried with Parson Drove woad its success was complete; the long sought-for blue colour fell in abundance. Prof. Beijerinck tells me that in the month of September he obtained 09 per cent. of pure indigo-blue from plants grown in Holland.

A considerable number of experiments have been made with the Parson Drove woad, the outcome of which may thus be summarised. The elaborate precautions for excluding the air are not absolutely necessary-simply pouring boiling or nearly boiling water on fresh woad leaves, so that they are completely covered, answers well enough. If to the infusion thus obtained caustic potash, caustic soda, strong ammonia or lime-water be added; the colour changes from yellowish to greenish. Any woollen fabric now dipped into this alkalised infusion will, on exposure to the air, pass from greenish to blue-not the dark blue one had expected, but a beautiful pale azure blue. This change takes place at once if the fabric be.immersed in any of the dilute mineral acids. The blue colour thus obtained cannot be called fast, as it will not withstand the action of alkalis or even of soap. It is very subject to variation, being often greenish-blue, grey, or even dove colour. This depends on the age and quality of the woad leaves, as well as on the details of manipulation. In brief, the process consists in simply making an infusion and treating it first with a caustic alkali, then with an acid. The following points have, however, to be attended to: the leaves must be young, they must be fresh, the water must be boiling or nearly so, the infusion must not be left too long before the alkali is added, nor must the addition of the acid be too long delayed. The infusion must be cold before it is treated. If these precautions be not observed, instead of the indigo-blue, that peculiar brownish-black compound is formed which is the bête nour of the woad experimenter.

In order to determine the quantity of indigo in Parson Drove woad in plants of various ages: half a kilogramme of leaves, $28,30,34$ and 66 days old, was found to yield respectively I 5 , $2 \cdot 4,2 \cdot 1$, and 0.6 grammes of impure indigo.

The indigo obtained from different experiments varied much in colour; one specimen was an exceedingly beautiful light blue; mostly, however, it was dark blue, which became when dry more or less green. When this, however, was powdered and dissolved by the aid of slaked lime and ferrous sulphate, it dyed cotton articles bright indigo-blue. With regard to the time the leaves should be allowed to infuse, a series of experiments in which 30 c.c. of an infusion were examined at the end of 30 minutes, $1 \frac{1}{2}, 2,3,6,9,12,24$ and 48 hours, showed that the first 30 c.c., i.e. at the end of 30 minutes infusion, contained as much indigo as any of the others while after the 6th hour the indigo-blue was replaced by the ilack-brown precipitate. It is probable that the agitation of the vessel in pouring off the successive quantities was the cause of this, for I have obtained indigo-blue from infusions at the end of IO or I 2 hours when they have not been disturbed.

May I ask if any of your readers can help me by suggesting the process by which the mediæval dyers got a blue dye from the prepared woad? Indigo was not introduced into Europe as a commercial article till the middle of the sixteenth century, and even then its employment was for some considerable time more or less prohibited by legal enactments. That woad was used in this country long prior to this is shown by the indenture which still exists between the woad merchants of Amiens and 1899 
the citizens of Norwich, dated June 29, I 286. That the culture and preparation of woad was practically the same in the time of Ruellius (I536), Crolachius (I575), Wedelius (I675), and Ray (i686) as it is now their writings show. It is probable some very simple process was used by the dyers in these olden times, as simple as that by which the blue colour can be obtained from the fresh plant -at any rate, less complicated than the woadvat Helliot describes in $175^{\circ}$ for dyeing with woad and indigo, and which is given, with variations. in encyclopedias down to the present time.

Charless B. Plowright.

\section{CONTACT ELECTRICITY.}

$A \mathrm{~T}$ the meeting of the Physical Society, a few weeks ago, when the subject of Contact Electricity was under discussion, the President was asked by his friendly opponents to commit himself to a definite interpretation of the fundamental equation, and to a precise statement as to what quantity he recognised as "contact potential difference." Prof Lodge dic not then comply with the request, but he promised to address the Society upon "Contact Electricity" at their annual general meeting on February 9. It is rather a matter for regret that this ancient feud is so near to amicable settlement. The controversy has held its own for a little more than a century, and throughout that time it has acted as a never-failing stimulus to research in the laboratory. Physicists are now retracing the steps of their arguments, revising their definitions, amending their phrases, and trying hard to understand one another's parlance. No scientific dispute can outlive such precautions.

The case for both sides has frequently been stated. Perhaps the best account consistent with brevity is that given in Prof. A. Gray's "Magnetism and Electricity," Chap. xii. This, in common with all modern summaries of the subject, is admittedly derived from Prof. Lodge's British Association Report of 1884 . Those who desire to bring themselves into closer acquaintance with the latest developments of the argument should read the article on "Contact Electricity," by Mr. W. A. Price, in the Electrical Review of December 29, 1899. Mr. Price seeks to locate the dispute to the meaning of words, and chiefly to the word "potential." $\mathrm{He}$ explains that "potential" is essentially a property of a position in space, and that it implies neither the existence nor the absence of matter near or at a point of which potential is predicated. The expression "potential at a point" has per se no ambiguity. But when measurements of the potential at a point are required, the methods employed, from their indirect character, necessitate certain assumptions; and the quantity is no longer free from ambiguity. Potential is generally measured indirectly, as the result of an investigation of the electrical force in the neighbourhood of the given point. The value, so obtained, involves therefore the physical qualities of the fluid medium or media assnciated with the point, and these have no place in the primary definition of potential." There is, in fact, no experimental foundation for the statement that within a conducting body, not conveying electricity, potential has the same value at all points. Hence no conclusions can properly be drawn until physicists agree amongst themselves as to their cardinal definitions; and when this is accomplished, the controversy will have ceased.

\section{AGRICULTURAL EDUCATION.}

$W E$ are slowly realising that success in farming depends quite as much upon scientific knowledge as upon practical training. In other countries this fact has been fully appreciated for many years, and elaborate provision for the interests of agriculture forms a prominent feature of their educational systems. Similar provision has become a necessity for England, if we are to compete with them upon anything like equal terms. In furtherance of this ubject the Agricultural Education Committee, of which some of the most eminent men of science and agriculturists of the day are members, has recently issued certain definite proposals. Foremost amongst these is a recommendation that all the educational work of the Board of Agriculture should, like that of the Science and Art Department, be transferred to the new Board of Education. If the confusion, overlapping and wasteful expenditure of public money, which have resulted from the multiplication of central authorities, are to be avoided, it is essential that one authority alone should be responsible for the agricultural education of the country. It would be the function of this authority, aided by inspectors thoroughly familiar with the needs of the agricultural classes, and with the conditions of rural life, to secure an adequate provision of the various forms and degrees of instruction required by all those who are in any way concerned with the cultivation of the soil.

Such instruction must commence with the elementary school, for that is the foundation upon which the whole superstructure has to be built, and the Committee emphasises the importance of differentiating the curriculum of the rural from that of the urban school. This change is not advocated under the impression that it will stem the tide of migration from the country districts. A variety of social and economic causes combine to drive men from the villages into the towns. At the same time, on the principle that "as a twig is bent, so will the tree incline," it is hoped that if children were familiarised from their earliest years with the simple facts of nature, and encouraged to take an intelligent interest in them, a love of the country might be awakened, and the desire to remain in it certainly be strengthened. No suggestion of teaching agriculture or science as such is put forward : years ago, Prof. Huxley pointed out the futility of attempting to teach either one or the other in an elementary school. A rural curriculum should include elementary science lessons upon the life, growth and structure of plants, the habits of birds, animals and insects, the nature of the soil, and air and water, and the utility of the simpler methods of cultivation. These lessons should be illustrated by experiments, and be accompanied by practical work, appropriate to the agricultural character of the locality, done by the pupils themselves in gardens or on plots of ground attached to the school. They should be supplemented further by occasional visits to well-managed farms, and valuable assistance might be given by circulating amongst the teachers and pupils leafets, similar to the admirable " Nature-Study Leaflets" issued by the agricultural college in Cornell Uni. versity. In like manner girls should receive elementary instruction in cooking, domestic economy and hygiene. In either case the child will be developing those faculties, and forming those habits, which enable a boy to become a skilled labourer or a successful farmer, and a girl to become a competent servant or a capable housewife. To meet the difficulties of small schools, several parishes must combine to engage the services of a peripatetic teacher. There can be no doubt that in the grouping of villages and schools for educational purposes the solution of many of the problems of rural education will ultimately be found to lie.

As yet it is not easy to find properly qualified teachers, but the Committee suggests various ways in which they may be trained. At the normal colleges in France theoretical and practical instruction in agriculture is provided for the students by the departmental professors, and there does not appear to be any reason why students at some of the training colleges in England should not be similarly taught by the lecturers of the County Councils. It should be remembered that the rural school does not require an agricultural expert; such a teacher would inevitably give undue prominence to one aspect of elementary education, and it might reasonably be objected that an attempt was being made to capture the schools in the interest of one section of the community only. The rural teacher should have a general knowledge of the principles underlying the science of agriculture, and some practical knowledge of agricultural operations. Men so qualified will be rapidly forthcoming as the demand for them becomes more general. In the meantime existing teachers should be assisted to acquire the necessary experience by County Council lectures, practical demonstrations on farms and in gardens, and courses of instruction at agri. cultural colleges; special facilities by means of scholarships or bursaries should be offered to rural pupil teachers for a course of some duration at any institution where theoretical and practical instruction might be had.

It is necessary to insist upon the importance of the lower branches of agricultural education in view of the small attention which has hitherto been paid to them. The hope of the future lies in our having a constant relay of pupils from the elementary schools fitted to attend and profit by the more advanced classes and colleges. For the majority of rural children evening continuation schools afford the only opportunity for further instruction, and the Committee recommends that it should be made part of the duty of every county organisation (outside London and the county boroughs) recognised under Clause VII. 